\title{
An Empirical Study on the Improvement of College Students' Learning Motivation
}

\author{
Chengyu Changa, Yibing Xionga
}

\begin{abstract}
Combined with the actual work of universities, to build a harmonious organic whole work program is by "thought leading, teacher teaching, needs feedback and students' practice". To build an application platform based on innovation and entrepreneurship from the perspective of students' learning motivation and learning needs, helps the student strengthen the learning ability construction. Through improving students' work and learning ability, they will be willing to learn.
\end{abstract}

\section{Keywords}

Innovation and entrepreneurship, college students, learning motivation

Knowledge economy in the twenty-first century emerging, with the rapid development of science and technology, the human being is facing a new era. Under the background of the whole entrepreneurial environment, strengthening universities to promote the construction of fine style of study, cultivating high-quality talents with innovation spirit and ability to raise the enthusiasm of students, has become the inevitable demand of the new times.

\section{RESEARCH ON IMPROVING THE ENTHUSIASM OF COLLEGE STUDENTS BASED ON THE ENTREPRENEURSHIP ENVIRONMENT}

From May 29, 2015 to January 7, 2016, the authors carried out a survey on the improvement of students' learning initiative, and received 275 suggestions on strengthening the construction of style of study. The main problems are as follows:

Students' interest in learning needs to be improved. The way of university study is different from the high school age, and the students' independent learning interest is not enough.

The traditional mode of education has great limitations in classroom thinking, it is difficult to let the students be away from the computer and go out of the bedroom. There are also some students who will automatically block some boring course. Although some students are in the classroom, but they still did not listen to the teacher carefully.

Interest in the classroom needs to be promoted, teachers cannot teach fully in accordance with the books. And the teaching courseware is very old, sometimes, the students can know what the teacher will go to talk about in the class through the high grade students.

Due to the inertia of people, for many students, sometimes continuous learning will be inert. At the same time, a lot of students like delaying in doing

aJingdezhen Ceramic Institute, Jiangxi, China

\section{Correspondent Author:}

Yibing Xiong, Student Affair Office, School of Design, Jingdezhen Ceramic Institute, Xianghu lake campus, Jiangxi, China, 333403 
things, so the quality of the work will be greatly reduced. There is a phenomenon of individual students, they begin to do the homework until the teacher checks the homework, so the quality of homework will be greatly reduced; there is also a phenomenon in few students that some students even do not do homework.

Based on the above problems, we set the wisdom of all the people, and try to explore the construction of the study style of college students and the main measures of how to enhance the learning initiative. There are a large number of contemporary college students, so how to make them truly autonomously learn and improve their learning efficiency has become a hot issue in modern society. The lack of enthusiasm for learning has become a common problem for contemporary college students. To solve this problem, we must find out the causes of the problem from the root, and take different methods to solve the problem combined with the college students' learning psychology.

\section{THINKING OF IMPROVING THE ENTHUSIASM OF COLLEGE STUDENTS BASED ON THE ENTREPRENEURSHIP ENVIRONMENT}

It needs to promote the "four in one" work program, to construct a "thought leading, teacher teaching, demand feedback and student practice" of the overall coordination of the work program, closely combined with the actual situation in universities, to better help students improve their learning interest, stimulate learning potential, and enhance the enthusiasm of learning. Students' interest is the basis of learning, so we need to pay more attention to it.

It needs to strengthen the construction of a comprehensive platform. In the context of innovation and entrepreneurship environment, we need to build three classroom models: the first classroom (teaching classroom), the second classroom (practicing classroom), and the third classroom (new media classroom), to improve student learning enthusiasm through this method. University education is very different from high school education, the university teaching puts more emphasis on students' initiative in studying peocess. Through different ways of teaching mode to help students grow up, students can accept different learning and training in the university.

It needs to help students enhance the "active learning" ability. To urge the students to strengthen the ability of self-management, learning consciousness, and independent innovation. To meet the needs of students at different levels, so that individuals needs can be harmonious coexistence with the community, and to grasp the advantages of students in different times, then we can stimulate the enthusiasm of students learning.

\section{PRACTICE ON IMPROVING THE ENTHUSIASM OF COLLEGE STUDENTS BASED ON THE ENTREPRENEURSHIP ENVIRONMENT}

According to the 2014 college graduates' employment quality annual report of 75 universities directly under the Ministry of Education, there are obvious changes as follows: Graduates are no longer keen on national enterprises, regional mobility is becoming strengthened, more and more college students choose to innovate. In the new business environment, how to improve the enthusiasm of college students has become a very important problem. The authors put forward countermeasures mainly from four levels, which is "the school, professional teachers, counselors, and students themselves".

\section{The College Level}

We should fully interpret the professional development prospects, so that students will clearly know "who sent me to university, why I should go to 
university, and other issues". This can help students find themselves and strengthen the motivation to learn. For students, the school is the focus of their attention. At the same time, the school is the power that encourages them to work hard. Therefore, the university needs to continue to encourage students, and find the problem of students, then help students solve the problem in time.

Cooperating with enterprises and recommending students to internship during the holidays. Business representatives came to preach their business unique advantage and broaden the professional skills and also built an effective way to its training of combat platform. After the lecture, the students have pledged to further enrich themselves and let their wings more rich, in order to meet the future opportunities and challenges. After the presentation, many students want to further enrich themselves, so that their wings can be more abundant, in order to meet the opportunities and challenges in the future.

It needs to establish remote education and training system; to improve the online education; to open up the students' eyes learning BBS (Bulletin Board System) column; to use the QQ group, blog, micro channel group, and so on. It also needs to establish "innovation and entrepreneurship learning garden", the creation of "mobile education class", and so on, and to strengthen the study and education of students during the holidays and internships.

The school launched the "Lecture Room" to promote the construction of study style. It is orchestrated around the "100 forum", building "every month a lecture" projects, actively inviting domestic and foreign well-known experts and scholars or industry leading figures and masters of art, and so on. The school has organized "watch design-my design attitude and design life", "how to calculate good design", and other academic lectures, to stimulate students' creative thinking, improve students' artistic accomplishment. At the same time, the school took the "Red May Science and Technology Culture Festival" as an opportunity, combined with its own characteristics. The school also launched the first "design art college art creation week", during the festival, it held many academic lectures, art salon, competitive games, and so on.

It is essential to coordinate the relationship among the three elements of the school, society, and family. College, society, and family play different roles and functions in the improvement of students' learning enthusiasm. Among these three, there are many aspects of mutual restraint and mutual influence. Therefore, we should make full use of the functions of school education, social education, and family education, and coordinate the relationship among them to improve students' learning enthusiasm.

In addition, we also require the class to create advanced and collective class, excellent style of study style, the concept of excellent group branch. By holding class atmosphere and construction of study style theme meeting and other forms to publicize the concept, calling for the class to strive to create advanced collective, striving to be advanced individual. Requiring junior grade students to be concentrated late self-study. It also needs to help students to create a good learning atmosphere, the optimization of class atmosphere and style of study construction environment. In each class, we can set up different learning interest groups, sports teams in order to promote the class atmosphere and style of study construction. So we can build a good platform for students in school. At the same time, we can also carry out new career design, career planning and design of graduates, learning competitions, academic reports, scientific and technological innovation, and other activities to promote the construction of study style. Since implementing the "system, project, standardized" work thinking in the entrepreneurial environment, the objectives of class work were more clear and the work of thinking was also more clear. In this background, by greatly enhancing the cohesion of the class, and significantly improving class 
atmosphere and style of study, the construction of study atmosphere has made periodicity achievements.

\section{The Professional Teachers' Level}

Teachers need to fully interpret the importance of teaching materials and curriculum.

The classroom is the main place for students to learn, so teachers need to increase the interest of teaching, in order to enhance the learning of knowledge for students attractiveness. Combining teaching content with the students' interest, students are interested in learning, but also learn the knowledge; such as a visual language lesson, when the teacher talks about the use of the camera, combined with the hit drama "My Love From the Star", students feel that the effect is very good.

To help students improve understanding of learning the social significance of a subject (or material) with personal relationships, especially the students whose major are design, we should try to carry out some DIY theme activities, or complete a design theme in time. It is best to show the place moved from indoor to outdoor, the design needs to accept the masses' view and interesting works will be more prominent. It is important to advocate a kind of democracy, harmony, and a positive classroom atmosphere in teaching, to change teachers" "absolute authority"; the teachers and students are equal in personality. Students with good grades and bad grades are equal in personality, every teacher should respect their students in personality. Homework can be completed by the group division for full participation. Let students know that cooperation is very important, we can make the students as many as possible to participate in the discussion and interaction, and to mobilize enthusiasm in the process of communication.

It needs to pay more attention to the emotional education of college students. When teachers' love and pursuit of career was poured into the whole process of teaching, it will exert a subtle influence on the students.

\section{The Instructor Level}

To carry out some interesting extracurricular activities, to use the team as a unit, it does not need a lot of people. The purpose is to prevent some students from giving up halfway, and expand the influence of the activities, using new media in the process of activities. Through carrying out the use of the library lectures, or holding campus reading day activities, more students can understand the benefits and functions of the library.

To carry out curriculum research team, it will help students communicate with each other on knowledge and experience. Encouraging students to give advice to teachers, letting students choose favourite course by themselves, and strengthening learning skills of students in certain aspects.

To carry out incentive system, it will reward students with good grades.

It is important to cultivate students' teamwork spirit, such as fostering advanced models, helping junior students develop senior mentoring. Mobilizing the enthusiasm of student party members, clearing high grade student party members contacting junior grade student system. Taking "1 plus 1, face to face" helping form, prompting students to make progress together.

Organizing learning method and the exchange of experience meeting, to carry out "one student help one student" campaign. The class should hold regular exchange of experience meeting in learning, inviting outstanding students to introduce the process of growth and learning methods; so that students will further clarify the purpose of learning, make a correct attitude towards learning, but also improve learning methods and consciously participate in learning. And striving to create a strong "learning excellence, advanced" atmosphere, and promoting a good style of study.

\section{Students Level}

Students should actively make analysis of their own, to realize the importance of learning. And students 
need to discover what they really like, then analyze it. Finding what they can do, what to do, and what can not do, starting from thier own target, maintaining curiosity and thirst for knowledge, continuing to ask questions. So their learning interest will beome better.

It needs to improve their collective sense of honor. Making students gradually integrate into the class team, to recognize that their own studying is also related to the class collective studying achievements.

\section{Social Management Level}

The authors found in the research of Jingdezhen that the government specially established the university student entrepreneurship park, in order to support college students to start their own business. It contains hundreds of studios, and there are special dormitories, just giving services for graduates from college. A lot of students and graduates do their own business in the building. Here, the students not only enjoy the preferential policies of the government, but also help each other and are mutually incentive.

\section{CONCLUSIONS}

Therefore, in the context of the current innovation, we need to adopt a modern way to promote the construction of college learning atmosphere. It is important to let the outstanding students exert their influence, and share the knowledge and practice experience of the university. Through the excellent management to promote the construction of the style of study, and further meet the needs of students, it will enhance students' learning initiative. In the course of the study, the authors used the method of positivism research. On the basis of learning advanced experience and finishing the existing results, it provides reference model and development path. And according to the university development resources and the actual working conditions, it is necessary to promote the characteristics of the work strategy. So universities can promote the construction of the style of study. Finally, we can enhance the motivation of learning and promote students to grow healthily. Although there are some problems in college education, the authors believe that as long as educators continue to work hard, we will promote the development of Chinese education.

\section{Funding}

This paper is supported by the research and practice of improving college students' learning initiative in innovation and entrepreneurship environment in the teaching and research reform project of Jingdezhen Ceramic Institute in 2015 (No. 007-212050).

\section{References}

Liu, X. J. 2016. "A Study of the Difference Among College Students With Different Family Background." Fujian Normal University.

Wang, Z. R. 2015. “'Broad Spectrum' Innovation and Entrepreneurship Education System." Educational Research 2015(5):51-58.

Wang, Z. W. 2016. "A Study on the Influence Factors of Mobile Learning on College Students' Learning Performance-Based on the Cognitive Load Theory." Donghua University.

Xiang, L. 2014. "On Promoting the Innovation and Entrepreneurship Education in Colleges and Universities." Ideological and Theoretical Education 2014(8):89-92.

Yu, L. and G. Q. Zhang. 2016. "The Theoretical Exploration of Moral Education of College Students in Media Era." Continuing Education Research 2016(4):103-106.

\section{Bios}

Yibing Xiong, master, lecturer, Jingdezhen Ceramic Institute, Jiangxi, China; research field: ideological and political education.

Chengyu Chang, master, lecturer, Jingdezhen Ceramic Institute, Jiangxi, China; research field: ideological and political education. 